\title{
The Brave New (American) World of International Investment Law: Substantive Investment Protection Standards in Mega-Regionals
}

\author{
Stephan W. Schill* \& Heather L. Bray** \\ University of Amsterdam, The Netherlands
}

\begin{abstract}
Mega-Regionals are transforming and shaping the future of international investment law, concerning both the settlement of investment disputes and the substantive disciplines governing investor-state relations. Focusing on the latter, the present article shows how Mega-Regionals depart from the so far dominant European model of investment protection by going beyond crudely worded post-establishment protections for foreign investment. Instead, Mega-Regionals pursue the twin policy goals of investment liberalization through greater market access commitments and strengthening state control by ensuring host governments sufficient space to regulate in the public interest. In light of these policy goals, and considering the deeper reasons for structural changes to the investment rules in Mega-Regionals, the article argues that the models and conceptual foundations of Mega-Regionals build on prototypes first developed in the context of U.S. and NAFTA investment practices. This suggests that the future of international investment law will be shaped to a considerable extent against the background of U.S. experiences, rather than be forged anew by the mechanics of international diplomacy and negotiation.
\end{abstract}

* Professor of International and Economic Law and Governance at the University of Amsterdam; Member of the List of Conciliators of the International Centre for Settlement of Investment Disputes; German Rechtsanwalt and Attorney-at-Law (New York); Dr iur (Frankfurt am Main 2008); LLM (NYU 2006); LLM (Augsburg 2002). He can be reached at schill@uva.nl.

** Researcher and PhD Candidate at the University of Amsterdam; Barrister and Solicitor of the Law Society of Upper Canada; LLB (University of New Brunswick 2010); LLM (Western University 2011). She can be reached at heather@young-bray.ca.

The research leading to this article has received funding from the European Research Council (ERC) under the ERC Grant Agreement $N^{\circ} 313355$, as part of the research project on 'Transnational Private-Public Arbitration as Global Regulatory Governance: Charting and Codifying the Lex Mercatoria Publica' (LexMercPub) carried out at the University of Amsterdam. The article is a revised and expanded version of a paper presented at the conference "Mega-Regionals and the Future of International Trade and Investment Law", which was organized on 23 and 24 October 2014 in Dresden, Germany by the Research Centre for International Economic Law at the University of Dresden and the affiliated research project "Global TranSAXion". The article will also appear in MEga-Regional TRADE Agreements and the Future of International Trade and InVestment LaW (Thilo Rensmann ed., 2017). It was finalized based on material available as of 30 June 2016. 


\section{CONTENTS}

I. The Advent of Mega-Regionals: Whose Brave New World? 421

II. Investment Liberalization Through Mega-Regionals ................425

A. Non-Discriminatory Market-Access .................................426

B. Performance Requirements ...............................427

C.Limitations on Investment Liberalization ......................428

III. Strengthening State Control Through Mega-Regionals ...............429

A. Limiting the Scope of Application of Investment

Protection Standards .429

B. Reformulation of Substantive Standards of Treatment .433

C. Institutional Safeguards

IV. The Impact of Mega-Regionals on International InVEstment LaW..... 440

A. Fusing Mega-Trends in International Investment Law 441

B. Structural Differences Between Mega-Regionals and Traditional BITs .443

V. Concluding Remarks 


\section{The Advent of Mega-Regionals: Whose Brave New World?}

International investment law is in a process of significant transformation, driven by the conclusion and continued negotiation of so-called Mega-Regionals. Being formed between countries or regions with a major share of world trade and foreign investment flows, Mega-Regionals emerge as deep integration partnerships. Their substantive obligations typically go beyond existing disciplines established in the World Trade Organization (WTO), integrate trade and investment disciplines in the same agreements, and often address (at least some) interaction between economic disciplines and competing concerns, such as the environment or labor standards. In addition, Mega-Regionals regularly create their own institutional infrastructure, including for purposes of dispute settlement and for the operationalization of intergovernmental or inter-agency regulatory cooperation, amongst others. Posing challenges to both the WTO's multilateral trading system and the traditional mechanism of investment governance through bilateral agreements with their strong focus on investment dispute settlement, Mega-Regionals show their potential to form the nucleus of the global economic governance of the future, in respect of both trade and investment. ${ }^{1}$ With a sense of wonder about the prospects of this new future, one is reminded of Shakespeare's words: "O brave new world.".

Commonly cited examples of Mega-Regionals are the Trans-Pacific Partnership (TPP), which was concluded in October $2015,{ }^{3}$ as well as the Transatlantic Trade and Investment Partnership (TTIP) ${ }^{4}$ and the Regional Comprehensive Economic

\footnotetext{
While consensus does not exist on the definition of what constitutes a Mega-Regional, certain characteristics are named in a recurring fashion: 1) the agreement is usually negotiated between a larger number of parties; 2) the countries represent a large share of global trade, gross domestic product (GDP), and population; and 3) the substance of the agreements goes beyond existing commitments under the World Trade Organization (WTO), regional trade agreements, and bilateral investment treaties (BITs). To this list, a fourth criterion is sometimes added, namely the ability of the agreement to transform into a pillar of economic governance. See Global Agenda Council on Trade and Foreign Direct Investment, Mega-Regional Trade Agreements: Game-Changers or Costly Distractions for the World Trading System? (2014) 7, available at http://www3.weforum.org/docs/ GAC/2014/WEF_GAC_TradeFDI_MegaRegionalTradeAgreements_Report_2014. pdf; see also Peter Draper, Simon Lacey \& Yash Ramkolowan, Mega-Regional Trade Agreements: Implications for the African, Caribbean, and Pacific Countries 8 (ECIPE Occasional Paper No. 2/2014), available at http://www.ecipe.org/app/uploads/2014/12/ OCC22014_pdf.

2 William Shakespeare, The Tempest (Virginia Mason Vaughan \& Alden T. Vaughan, eds., Arden Shakespeare, 1999), Act 5, Scene 1, 182-83.

3 There are 12 countries that signed the TPP, namely Brunei, Chile, New Zealand, Singapore, Australia, Malaysia, Peru, the United States, Vietnam, Canada, Japan and Mexico. See Office of the United States Trade Representative, Trans-Pacific Partnership Agreement, available at https://ustr.gov/trade-agreements/free-trade-agreements/trans-pacific-partnership/tpp-full-text (last visited May 12, 2016).

4 The only indication as to the possible content of the investment chapter in TTIP stems from the proposal made by the EU. See Proposal of the European Union for Investment Protection and Resolution of Investment Disputes, Nov. 12, 2015, available at http://trade.ec.europa. eu/doclib/docs/2015/november/tradoc_153955.pdf [hereinafter EU TTIP Proposal].
} 
Partnership (RCEP), ${ }^{5}$ which are both currently under negotiation. While often little is known about the precise content of the agreements under negotiation beyond (at times incompletely) published or even leaked negotiation texts and negotiating mandates, their impact on international economic law is foreshadowed by the content of other recent major regional trade and investment agreements that may not themselves qualify as Mega-Regionals, but whose participants also partake in the negotiation of Mega-Regionals and more generally in the development of models for such agreements. Examples on point are the trade and investment treaty practice of the Association of Southeast Asian Nations (ASEAN), including the ASEAN Comprehensive Investment Agreement (ACIA) ${ }^{6}$ and so-called ASEAN+ agreements between ASEAN and third-countries, ${ }^{7}$ and the trade and investment agreements currently being negotiated by the European Union (EU), in particular the recently finalized Comprehensive Economic and Trade Agreement (CETA) with Canada ${ }^{8}$ and the Free Trade Agreement with Singapore. ${ }^{9}$

While it is clear that the content and institutional structures of both international trade law and international investment law are going to be deeply transformed in the years to come through the negotiation and conclusion of these agreements, calling the jury on the effect of Mega-Regionals on the debate about multilateralism versus bilateralism in international economic governance, ${ }^{10}$ on changes to power relations

$5 \quad$ RCEP is negotiated among 16 countries: the 10 Members of ASEAN and six countries with which ASEAN has existing free trade agreements (FTAs), that is, Australia, China, India, Japan, Korea, and New Zealand. See Amokura Kawharu, The Admission of Foreign Investment Under the TPP and RCEP: Regulatory Implications for New Zealand, $16 \mathrm{~J}$. WORLD INV. \& TRADE 1058 (2015).

6 ASEAN Comprehensive Investment Agreement (ACIA), Feb. 26, 2009, available at http://cil.nus.edu.sg/rp/pdf/2009\%20ASEAN\%20Comprehensive $\% 20$ Investment $\% 20$ Agreement-pdf.pdf.

7 These include, among others, the Agreement Establishing the ASEAN-Australia-New Zealand Free Trade Area, Feb. 27, 2009, available at https:/www.asean.fta.govt. nz/assets/_securedfiles/FTAs-agreements-in-force/AANZFTA-ASEAN/AgreementEstablishing-the-ASEAN-Australia-New-Zealand-Free-Trade-Area-1.pdf [hereinafter ASEAN-AUS-NZ FTA]; the Agreement on Investment of the Framework Agreement on the Comprehensive Economic Cooperation between the Association of Southeast Asia Nations and the People's Republic of China, Aug. 15, 2009, available at http:// fta.mofcom.gov.cn/inforimages/200908/20090817113007764.pdf [hereinafter ASEANPRC Investment Agreement]; the Agreement on Investment under the Framework Agreement on Comprehensive Economic Cooperation Among the Governments of Southeast Asian Nations and the Republic of Korea, Jun. 2, 2009, available at http://www. thaifta.com/trade/askr/akia.pdf [hereinafter ASEAN-Korea Investment Agreement].

8 Canada-European Union Comprehensive Economic and Trade Agreement (CETA), Feb. 29, 2016, ch. 8, available at http://rade.ec.europa.eu/doclib/docs/2016/february/ tradoc 154329.pdf.

9 EU-Singapore Free Trade Agreement, Oct. 8, 2014, ch. 9, available at http://trade. ec.europa.eu/doclib/docs/2014/october/tradoc_152844.pdf [hereinafter EU-Singapore FTA].

10 See the debate between Jagdish Bhagwati and Richard Baldwin on whether regionalism is considered a building block that helps achieve multilateralism or a stumbling block for multilateral world trade. Bhagwati considers regionalism as a stumbling block, whereas Baldwin finds that regionalism is a building block towards a multilateral trade regime. Jagdish Bhagwati, Termites in the Trading System: How Preferential Agreements Undermine Free Trade (2008); Richard E. Baldwin, Multilateralising Regionalism: 
among nations,${ }^{11}$ and on the relationship between economic interests and competing public concerns and regulatory powers ${ }^{12}$ is probably too early. Too much depends on whether these agreements will overcome wide-spread popular opposition, what further concessions may be made, for example, to concerns for human rights, environmental protection, and corporate responsibility, how these agreements are going to be used and implemented in practice and what their relationship with the existing multilateral trading system will be. What we can consider already, by contrast, is who the key actors are that drive the proliferation of Mega-Regionals and, above all, which actors shape the models and conceptual foundations these agreements build on. Who, in other words, are the rule-makers and rule-shapers that influence the content of Mega-Regionals through their ideological, ideational and conceptual leadership? The United States, the EU, and actors in Asia, above all China, are obvious contenders for leadership roles.

In developing an answer to the question of who shapes the future of international economic law, in the present article we do not look comprehensively at the full range of subject-matters covered by Mega-Regionals and other important free trade agreements. Instead, we limit ourselves to rules governing the relation of host states and foreign investors, principally as found in the investment chapters in TPP, CETA, ACIA, and ASEAN+ agreements, supplemented with occasional references to the most recent EU negotiation draft for TTIP's investment chapter. Moreover, our focus is on the substantive rules governing investor-state relations, to the exclusion of rules on dispute settlement. ${ }^{13}$ This limitation is due to the fact that questions of investment dispute settlement are much more in flux than questions of substance where global consensus, in our view, is more clearly emerging. ${ }^{14}$

Spaghetti Bowls as Building Blocks on the Path to Global Free Trade, 29 The World ECONOMY 1451 (2006).

11 See, e.g., Andrew Lang, World Trade Law After Neoliberalism: Re-imagining the Global ECONOMIC ORDER 43-53 (2011).

12 See, e.g., Markus Wagner, Regulatory Space in International Trade Law and International Investment Law, 36 U. PA. J. InT'L L. 1 (2014); Ingo Venzke, Making General Exceptions: The Spell of Precedents in Developing Article XX GATT Into Standards for Domestic Regulatory Policy, 12(5) German L. J. 1111, 1116-37 (2011); Aikaterini Titi, The Right to Regulate in International Investment Law (2014).

13 For an in-depth analysis of the envisaged dispute settlement disciplines in Mega-Regionals, see Stephan W. Schill, Authority, Legitimacy, and Fragmentation in the (Envisaged) Dispute Settlement Disciplines in Mega-Regionals, in Mega-Regional Agreements: TTIP, CETA, TiSA. New Orientations for EU External Economic Relations (Stefan Griller, Walter Obwexer \& Erich Vranes eds., 2017) (forthcoming).

14 Apart from lingering efforts in Latin America (see the contributions in Katia FachGómez \& Catharine Titi (eds.), Special Issue: The Latin American Challenge to the Current System of Investor-State Dispute Settlement, 17(4) J. WorLd Inv. \& Trade 511-699 (2016)), the debate about reforming investment dispute settlement is particularly vivid since the EU tabled a proposal generally to abandon arbitration as a mechanism to settle investor-state disputes and instead to establish an 'Investment Court System' which is to involve a permanent court-like body with an appeals mechanism and staffed by judges who are appointed by the state parties to the agreement, not anymore by the parties to a concrete dispute. See EU TTIP Proposal, supra note 4, subsec. 4. In CETA, Canada and the EU have already agreed to include this court-like system (CETA, supra note 8, art. 8.29), but it is an open question whether the United States is going to accede to the EU proposal or insist on what has to be considered its preferred model for investment 
The emerging consensus we see in reviewing the substantive rules governing investor-state relations, as we will outline in more detail in the following sections, is one that parts ways in several regards with the traditional lean European model that served as the basis for most of the more than 2,000 bilateral investment treaties (BITs) that were concluded since the late 1950s. ${ }^{15}$ Instead, the predominant model for rules governing investor-state relations in substance that we see emerge in Mega-Regionals and other modern trade and investment agreements is the one that has been pushed for by the United States (and to some extent also by Canada) for roughly two decades through evolving versions of the U.S (and Canadian) Model BITs ${ }^{16}$ and through the free trade agreements that the United States (and to a lesser degree Canada) is a party to, most importantly the North American Free Trade Agreement (NAFTA). ${ }^{17}$

In our view, the "brave new world" of international investment law is therefore to a large extent a "brave new American world". In its results, our argument resembles that by Wolfgang Alschner who is arguing that the evolution of international investment law generally has to be understood as an "Americanization of the BIT Universe". ${ }^{18}$ Together with Dmitriy Skougarevskiy, he has impressively shown that the United States' influence can be traced in the TPP by comparing its provisions to that of U.S. treaty practice and the 2012 U.S. Model BIT. ${ }^{19}$ The method we employ in the present article is however not an empirical text-as-data analysis, as that employed by Alschner and Skougarevskiy, but a traditional jurisprudential approach that analyzes and traces the evolution of legal concepts in the investment chapters of Mega-Regionals.

Two developments are key for the argument that the United States has assumed predominant rule-, idea-, and concept-shaping power in international investment law.

dispute settlement, that is, a reformed version of investor-state arbitration, as illustrated by the TPP (sec. B: Investor-State Dispute Settlement). Moreover, how other countries the world over are going to react to the EU proposal is still much too early to tell.

15 Zachary Elkins, Andrew T. Guzman \& Beth A. Simmons, Competing for Capital: The Diffusion of Bilateral Investment Treaties, 1960-2000, 60(4) INT'L ORG. 811-46 (2006).

16 See Kenneth Vandevelde, Bilateral Investment Treaties: History, Policy, and InterPRETATION (2010).

17 North American Free Trade Agreement (NAFTA), Dec. 17, 1992, 32 I.L.M. 296 and 695 (1993).

18 Wolfgang Alschner, Americanization of the BIT Universe: The Influence of Friendship, Commerce and Navigation (FCN) Treaties on Modern Investment Treaty Law, 5(2) Go. J.I.L. 455, 484 (2013). See also Wolfgang Alschner, State-Driven Change in International Investment Law and Its (Uncertain) Impact on Investor-State Arbitration: An Empirical Big Data Analysis (Unpublished PhD Dissertation, Graduate Institute Geneva, 2015).

19 Wolfgang Alschner \& Dmitriy Skougarevskiy, The New Gold Standard? Empirically Situating the Trans-Pacific Partnership in the Investment Treaty Universe, 17 J. WorLD Inv. \& TRADE 339 (2016). Similarly, other authors have shown that U.S. positions and NAFTA practice are predominant in reshaping the future of international investment law. For an analysis of the impact of U.S. positions on China see Axel Berger, Hesitant Embrace: China's Recent Approach to International Investment Rule-Making, $16 \mathrm{~J}$. World Inv. \& Trade 843 (2015); Axel Berger, Investment Rules in Chinese PTIAs A Partial "NAFTa-ization", in Preferential Trade and Investment Agreements: From Recalibration to Reintegration 297 (Rainer Hofmann, Stephan W. Schill \& Christian J. Tams eds., 2013). For an analysis of the evolving EU position see, e.g., August Reinisch, Putting the Pieces Together ... an EU Model BIT?, 15 J. World Inv. \& Trade 679 (2014). 
First, unlike the European model prior to the EU's involvement, the United States has always seen BITs as instruments for the protection of investments post-establishment as well as for the liberalization of market access for foreign investors. ${ }^{20}$ This vision has found its way into NAFTA and by now has become, to different degrees, and subject to many nuances, the predominant model for Mega-Regionals and modern trade and investment agreements. Most of these agreements, including the ones that the EU is currently negotiating, focus not only on the protection of existing investment (postestablishment), but include provisions on investment liberalization through market access (pre-establishment) (further discussed in Part II).

Second, the substantive investment standards found in Mega-Regionals and other important trade and investment agreements also follow evolving U.S. investment policies as laid down in the U.S. Model BITs of 2004 and $2012^{21}$ and in the practices that developed in the context of NAFTA in another respect. Investment chapters in Mega-Regionals, without exception, are much more specific than the broadly worded principles of investment protection contained in classical European BITs. They not only clarify and concretize the extent of investor rights, but also the scope of regulatory powers of host states through more precise treaty drafting and the inclusion of provisions that recalibrate the textual basis for the relationship between investment protection and host states' regulatory powers (further discussed in Part III). ${ }^{22}$ All in all, Mega-Regionals will therefore strengthen state control during the post-establishment phase, while, at the same time, introducing new limits on government powers in the preestablishment phase.

After zooming in on these developments, we consider some of the deeper structural reasons for the changes to the investment rules in Mega-Regionals that make the content of these agreements a good indicator for the future of international investment law more generally (see Part IV) and close with a reflection on the prospects of continued U.S. leadership in shaping the framework for international investment governance more generally (see Part V).

\section{Investment Liberalization Through Mega-Regionals}

Compared to traditional European BITs, the first major change in Mega-Regionals is their expansion to serve also as instruments of investment liberalization. European BITs, in contrast, generally focused on the protection of investments only after they had entered the host state, following the approach of customary international law,

20 The investment treaty practice of the United States has always been an exception in this respect, given that U.S. BITs have regularly also extended national and MFN treatment to market access. See Rudolf Dolzer \& Margrete Stevens, Bilateral Investment TREATIES 56-57 (1995).

21 U.S. Model BIT 2004, available at http://www.state.gov/documents/ organization/117601.pdf; U.S. Model BIT 2012, available at http://www.state.gov/ documents/organization/188371.pdf.

22 See also Caroline Henckels, Protecting Regulatory Autonomy Through Greater Precision in Investment Treaties: The TPP, CETA and TTIP, 19(1) J. INT'L Eco. L. 27 (2016). 
under which foreign investors do not have the right of entry or establishment. ${ }^{23}$ Mega-Regionals go further in this respect and follow the U.S. BIT practice of generally including greater market access commitments that aim at reducing restrictions on the entry of foreign investments and eliminating discrimination at the pre-establishment phase. ${ }^{24}$ Examples of investment liberalization provisions found in Mega-Regionals include national treatment and most-favored-nation (MFN) treatment at the pre-establishment phase (see Section A) and restrictions on performance requirements (see Section B). At the same time, Mega-Regionals maintain important exceptions and restrictions on investment liberalization (see Section C). In central aspects, these developments mirror the trend the United States has followed since the start of its BIT program in 1981 and later through its participation in trade and investment agreements, in particular under NAFTA.

\section{A. NON-DisCRIMINATORY MARKET-ACCESS}

The customary way of achieving liberalization is with the implementation of provisions that give investors non-discriminatory access to a foreign market or a right of establishment, which is traditionally incorporated through national treatment and MFN clauses. Both NAFTA and BITs involving the United States have traditionally applied non-discriminatory norms of national and MFN treatment to the entry of foreign investments. ${ }^{25}$ A number of Mega-Regionals likewise will provide both national treatment and MFN treatment concerning the entry and establishment of investments. ${ }^{26}$ These agreements accord investors and investments treatment no less favorable than the treatment accorded to domestic investors or investors of any third country in like situations. This usually covers the full range of investment activities from establishment, acquisition, expansion, conduct, operation, management, maintenance, use, enjoyment and sale or disposal of the investments.

CETA, among others, ${ }^{27}$ engages in this liberalization trend. It contains a provision that limits the ability of states to restrict investors' market access, ${ }^{28}$

23 UNCTAD, International Investment Arrangements: Trends and Emerging Issues 26 (UNCTAD Series on International Investment Policies for Development, United Na-

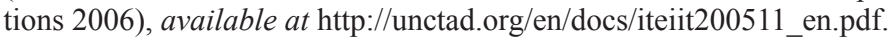

24 Id. 25.

25 See NAFTA, supra note 17, arts. 1102 and 1104.

26 Other agreements, such as the ASEAN-PRC Investment Agreement, supra note 7, arts. 4 and 5(1), include an MFN provision that extends to the admission and establishment of investments, but limit the national treatment protection to the post-establishment phase only. Again other agreements provide pre-establishment national treatment without providing for MFN treatment; see ASEAN-AUS-NZ FTA, supra note 7, ch. 11, art. 4. But see ASEAN-AUS-NZ FTA, supra note 7, ch. 8, art. 7, where the agreement stipulates that parties shall enter into future discussions regarding the application of the MFN treatment.

27 See further TPP, supra note 3, arts. 9.4 and 9.5; ASEAN-Korea Investment Agreement, supra note 7, arts. 3 and 4; ACIA, supra note 6, arts. 5 and 6 (all providing for preestablishment rights with respect to both national treatment and MFN obligations). The ACIA additionally lists in art. 1(a) as one of its main objectives the "progressive liberalization of the investment regimes of Member States" and includes liberalization as a guiding principle in art. 2(a) and (b) "with a view towards achieving a free and open investment environment in the region."

28 CETA, supra note 8, art. 8.4. 
providing for national and MFN treatment at the pre-establishment phase.${ }^{29}$ CETA adopts the "negative list"-approach, which opens all industries and sectors to liberalization except those that are specifically excluded in either of two annexes. ${ }^{30}$ This is in contrast to the "positive list"-approach that is adopted by the WTO General Agreement on Trade in Services (GATS), which only opens those sectors to admission that are listed in a schedule of commitments. ${ }^{31}$ The EU-Singapore Free Trade Agreement follows this latter "positive list"-approach. ${ }^{32}$

\section{B. Performance ReQuirements}

Other liberalization provisions in Mega-Regionals include prohibitions on the imposition of performance requirements. ${ }^{33}$ Prohibitions on performance requirements are considered liberalization provisions because "the imposition of performance requirements can be used to frustrate the right of establishment through the back door by allowing governments to impose significant demands that make an investment uneconomical." ${ }^{34}$

Mega-Regionals tend to include a prohibition on the use of performance requirements using one of two approaches. The first approach affirms the parties' commitment to the WTO Agreement on Trade-Related Investment Measures (TRIMs). ${ }^{35}$ The ACIA, amongst others,${ }^{36}$ adopts this approach. ${ }^{37}$ The second, and more liberalizing, approach is to follow NAFTA and restrict the use of performance measures beyond those specified in the TRIMs ${ }^{38}$ CETA has opted for this broader approach. It includes a long enumeration of prohibited performance requirements

Id. arts. 8.6 and 8.7.

Id. art. 8.15. See also ACIA, supra note 6, art. 6, n. 4.

31 General Agreement on Trade in Services (GATS), Apr. 15, 1994, 1869 U.N.T.S. 183, 33 I.L.M. 1167 (1994).

32 EU-Singapore FTA, supra note 9, art. 9.3. The national treatment provision extends nondiscriminatory treatment to the post-establishment phase only and there is no provision on MFN treatment.

33 Some agreements do not limit performance requirements. The ASEAN-PRC Investment Agreement, supra note 7, and the EU-Singapore FTA, supra note 9, are two agreements that seem to contain no limits on performance requirements.

34 Howard Mann, Investment Liberalization: Some Key Elements and Issues in Today's Negotiating Context 5 (Issues in International Investment Law: Background Papers for the Developing Country Investment Negotiators' Forum, 2007), available at http:/www. iisd.org/pdf/2007/inv_liberalization.pdf.

35 Agreement on Trade-Related Investment Measures (TRIMs), Apr. 15, 1994, 1868 U.N.T.S. 14.

36 See, e.g., ASEAN-AUS-NZ FTA, supra note 7, ch.11, art. 5; ASEAN-Korea Investment Agreement, supra note 7, art. 6.

37 See ACIA, supra note 6, art. 7(2). This article of ACIA also mentions that the Member States will engage, within a certain time frame, in a joint assessment of existing performance requirements and consider whether additional commitments should be made in the future.

38 The Canadian and U.S. BIT models follow the approach established in NAFTA. See Canada 2004 Foreign Investment Protection Agreement, available at http://www.italaw. com/documents/Canadian2004-FIPA-model-en.pdf [hereinafter Canada 2004 FIPA], art. 7; U.S. Model BIT 2012, supra note 21, art. 8. 
in connection with the establishment, acquisition, expansion, management, conduct or operation of investments in the host state. The prohibitions include, for example, restrictions on export requirements, domestic content requirements, and technology transfer requirements. ${ }^{39}$

\section{LIMITATIONS ON INVESTMENT LIBERALIZATION}

The inclusion of market access commitments notwithstanding, no Mega-Regional seeks to commit to unfettered liberalization. Importantly, the liberalizing effect of non-discrimination provisions and prohibitions on performance requirements depends in large part on what the countries exempt from market access or preestablishment requirements and on whether such provisions are included within the scope of investor-state dispute settlement. Placing limitations on investment liberalization provisions is not a new trend. The NAFTA parties, while extending national treatment and MFN treatment to the pre-establishment phase, and prohibiting the imposition of performance requirements, have nonetheless excluded certain measures, sectors and/or activities from liberalization. ${ }^{40}$ For example, NAFTA has detailed annexes that carve out sectors from MFN treatment (e.g. aviation, fisheries and maritime matters), ${ }^{41}$ reservations for existing non-conforming measures (e.g. transportation sector exceptions), ${ }^{42}$ as well as reservations for the introduction of future measures (e.g. excluding measures favoring Canada's aboriginal population) ${ }^{43}$

Mega-Regionals similarly follow in NAFTA's footprints in that they contain broad exceptions to national treatment, MFN treatment and the prohibition on performance requirements for existing, and sometimes even for the introduction of new, non-conforming measures. ${ }^{44}$ Also, Mega-Regionals may exempt certain sensitive areas from the scope of national treatment and MFN treatment, including government procurement and subsidies or grants. ${ }^{45}$ Additionally, some MegaRegionals temper the liberalizing effect of the agreement by omitting provisions on market access and prohibitions on performance requirements from the scope of investor-state dispute settlement. ${ }^{46}$ But even with these limitations, Mega-Regionals

39 CETA, supra note 8, art. 8.5. See also TPP, supra note 3, art. 9.10.

40 See, e.g., NAFTA, supra note 17, annex I (Canada has excluded measures favoring its aboriginal peoples from the scope of arts. 1102, 1103 and 1106).

41 See NAFTA, supra note 17, annex IV (Exceptions from Most-Favored-Nation Treatment).

42 See NAFTA, supra note 17, annex I (Reservations for Existing Measures and Liberalization Commitments).

43 See NAFTA, supra note 17, annex II (Reservations for Future Measures).

44 See, e.g., ASEAN-AUS-NZ FTA, supra note 7, ch. 11, art. 12; ASEAN-PRC Investment Agreement, supra note 7, art. 6; ASEAN-Korea Investment Agreement, supra note 7, art. 9; CETA, supra note 8, art. 8.15; TPP, supra note 3, art. 9.12.

45 TPP, supra note 3, art. 9.12(6); CETA, supra note 8, art. 8.15 (5); EU-Singapore FTA, supra note 9 , art. 9.2.

46 See, e.g., CETA, supra note 8, sec. F, art. 8.18. Similarly, the EU's TTIP negotiating mandate states that "ISDS shall not apply to market access provisions." See Council of the European Union, Directives for the Negotiation on the Transatlantic Trade and Investment Partnership between the European Union and the United States of America, 
on the whole seem to commit to improving market access for foreign investments and eliminating discrimination at the pre-establishment phase. This makes them potentially much more important in governing the future global economy than BITs, which were more limited concerning market access.

\section{Strengthening State Control Through Mega-Regionals}

In addition to promoting investment liberalization, Mega-Regionals are also recalibrating the substantive standards of treatment traditionally contained in BITs in order to strengthen the state's sovereign right to pursue public policies (so-called "policy space" or "regulatory space"). This goal is achieved, inter alia, by limiting the scope of application of investment protection standards in Mega-Regionals (Section A), making room for more policy space in the formulation of substantive standards of treatment (Section B), and introducing new institutional safeguards that allow contracting parties to increase control over investor-state dispute settlement (Section C). These aspects also build on models first developed in the context of U.S. and NAFTA investment practices.

\section{A. Limiting the SCOPE of Application of InVESTMENT Protection StandaRDS}

Limiting the scope of application of investment protection standards in the postestablishment phase is one way through which Mega-Regionals ensure additional policy space for host states. Such limits can be put in place through a variety of different provisions, including carve-outs (see Subsection 1) and general exceptions (see Subsection 2), but also "denial of benefits"-clauses (see Subsection 3) and "in accordance with host state law"-clauses (see Subsection 4). Many Mega-Regionals make use of all, others of parts, of these provisions and in one way or another build on trends seen prominently in U.S. and NAFTA approaches to recalibrating international investment protection rules.

\section{Carve-Outs}

Carve-outs are a popular tool in Mega-Regionals to protect host states' regulatory freedom by ensuring that certain measures are not subject to investment treaty disciplines in the first place. Mega-Regionals may offer three main types of carveouts: 1) carve-outs from the entire agreement; 2) carve-outs from specific treaty obligations; and 3) carve-outs for certain industries or areas of regulation. Notably, all three types of carve-outs can be found in U.S. and NAFTA practice. ${ }^{47}$

Brussels 10, Jun. 17, 2013, available at https://www.laquadrature.net/files/TAFTA\%20 \%20Mandate\%20_\%2020130617.pdf.

47 For example, the U.S. Model BIT 2012, supra note 21, provides a carve-out for taxation measures (art. 21), government procurement or subsidies or grants (art. 14(5)(a)-(b)); offers exceptions to the prohibition on certain performance requirements (art. 8(3)); and establishes an exception for certain measures related to intellectual property (art. 14(4)). 
Some of the most common carve-outs for entire Mega-Regional agreements include those for taxation measures, subsidies or grants, government procurement, and services supplied in the exercise of governmental authority. ${ }^{48}$ Other agreements provide carve-outs from certain treaty obligations, most notably national treatment, MFN treatment, the prohibition on performance requirements and rules on the nationality of senior management. As addressed above, ${ }^{49}$ Mega-Regionals tend to stipulate that non-contingent standards of treatment, the prohibition on performance requirements and rules on the nationality of senior management and board of directors do not apply to non-conforming measures (existing, continuing or amending).$^{50} \mathrm{~A}$ final type of carve-out found in Mega-Regionals is for specific industry sectors, such as audiovisual services,${ }^{51}$ cultural industries, ${ }^{52}$ or air services ${ }^{53}$ Other sensitive areas, such as financial services ${ }^{54}$ or sovereign debt, ${ }^{55}$ also benefit

$48 \quad$ ACIA, supra note 6, art. 3(4); ASEAN-PRC Investment Agreement, supra note 7, art. 3(4); ASEAN-AUS-NZ FTA, supra note 7, ch. 11, art. 1(2); ASEAN-Korea Investment Agreement, supra note 7, art. 2(2). See further CETA, supra note 8, art. 8.15, which excludes government procurement and subsidies, or government support relating to trade in services, from the scope of the market access, national treatment, MFN treatment, and senior management and board of directors provisions. CETA's treatment of taxation measures is more sophisticated than a simple carve-out and tries to balance taxation powers and investment protection in a more fine-tuned manner. See CETA, supra note 8, art. 28.7.

49 See supra Part II, Sec. C.

50 ACIA, supra note 6, art. 9 (provisions on national treatment and on senior management and board of directors shall not apply to non-conforming measures); ASEAN-PRC Investment Agreement, supra note 7, art. 6 (national and MFN treatment shall not apply to non-conforming measures); ASEAN-AUS-NZ FTA, supra note 7, ch. 11, art. 12 (national treatment and, in the case of Laos, the prohibition on performance requirements do not apply to non-conforming measures); TPP, supra note 3, art. 9.12 (national treatment, MFN treatment, performance requirements, and provisions on senior management and board of directors do not apply to non-conforming measures). The TPP, supra note 3, art. 9.12 includes these carve-outs and adds that national treatment, MFN treatment, and the rules on senior management and board of directors do not apply to government procurement, subsidies or grants. The EU-Singapore FTA, supra note 9, art. 9.3 exempts subsidies, grants, procurement and audio-visual services from the scope of the national treatment provision and also includes a special carve-out in relation to Singapore in annex 9-D.

51 EU-Singapore FTA, supra note 9, art. 9.3(b) (audio-visual services); CETA, supra note 8, art. 8.2(3) (audio-visual services for the EU).

52 CETA, supra note 8, art. 8.2(3) (cultural industries for Canada).

53 Id. art. 8.2(2)(a) (air services).

$54 \quad I d$. art. 8.3(1). The investment chapter does not apply to financial services, which is covered by Chapter Thirteen of CETA. This Chapter also contains investment protection rules, but modifies them to grant additional policy space; see CETA, supra note 8, art. 13.16 (prudential carve-out) and art. 13.17 (specific exceptions). The TPP, supra note 3 , art. 9.3(3) similarly contains a separate chapter dealing with financial services. Like CETA, this chapter also provides room for policy space that goes beyond that available in other areas. See TPP, supra note 3, art. 11.11 (exceptions).

55 The TPP, supra note 3, art. 9.1 in the definition of an investment includes "other debt instruments and loans" but in a footnote clarifies that "some forms of debt, such as bonds, debentures, and long-term notes, are more likely to have the characteristics of an investment, while other forms of debt, such as claims to payment that are immediately due and result from the sale of goods or services, are less likely to have such characteristics." In its annex 8-B (Public Debt), CETA limits the application of investment treaty standards in respect of sovereign debt restructurings. 
from modification to the general rules that grant additional safeguards for states' policy space.

\section{General Exception Clauses}

In addition to carve-outs, Mega-Regionals also regularly include general exception clauses that clarify that investment treaty disciplines do not override the governments' right to take measures for the protection of competing concerns. General exception clauses appear in a variety of forms and contexts and may vary in their content. Often they are modelled on Article XX of the General Agreement on Tariffs and Trade (GATT) and Article XIV of the GATS. General exception clauses permit states to take measures that, for example, are necessary to "protect public morals or to maintain public order," "to protect human, animal or plant life or health," 57 "to secure compliance with laws or regulations," 58 to protect "national treasures of artistic, historic or archaeological value," 59 or for the "collection of direct taxes." Interestingly, however, NAFTA has not taken this path. ${ }^{61}$ Similarly, the TPP and the 2004 and 2012 U.S. Model BITs borrow from GATT Article XX, but only to set out exceptions on the prohibition on performance requirements. ${ }^{62}$ The issue of general exceptions may therefore be an area where at least some Mega-Regionals escape the influence of the United States.

CETA, for example, includes a general exception clause that is contained in a separate chapter. ${ }^{63}$ In fact, Article 28.3 of CETA contains two exceptions. The first is found in paragraph one and simply incorporates GATT Article XX into the Agreement. ${ }^{64}$ The second paragraph contains another general exception clause, which is also modelled on GATT Article XX, but contains slight differences. For example, unlike the GATT model, CETA provides an exception for measures that are necessary for the "prevention of deceptive and fraudulent practices" or for the "protection of the privacy of individuals in relation to the processing and dissemination of personal data." ${ }^{95}$ The EU-Singapore Free Trade Agreement also

56 ACIA, supra note 6, art. 17(1)(a); ASEAN-PRC Investment Agreement, supra note 7, art. 16(1)(a).

57 ACIA, supra note 6, art. 17(1)(b); Canada 2004 FIPA, supra note 38, art. 10(1)(a); ASEAN-PRC Investment Agreement, supra note 7, art. 16(1)(b).

58 ACIA, supra note 6, art. 17(1)(c); Canada 2004 FIPA, supra note 38, art. 10(b); ASEANPRC Investment Agreement, supra note 7, art. 16(1)(c).

59 ACIA, supra note 6, art. 17(1)(e); ASEAN-PRC Investment Agreement, supra note 7, art. 16(1)(e).

60 ACIA, supra note 6, art. 17(1)(d); ASEAN-PRC Investment Agreement, supra note 7, art. 16(1)(d).

61 NAFTA, supra note 17, art. 2101 incorporates GATT art. XX exceptions, but this article explicitly does not apply to the investment chapter. The Canada 2004 FIPA, supra note 38 , art. 10 , however, contains a general exceptions provision that is very similar to GATT, art. XX.

62 TPP, supra note 3, art. 9.10(3)(d) provides a carve-out for the general prohibition for certain performance requirements when they, for example, are necessary to protect human, animal, or plant life or health.

63 See CETA, supra note 8, art. 28.3(1) and (2).

64 Id. art. 28.3(1).

${ }_{65} I d$. art. 28.3(2)(c). 
has a general exception clause, which applies, however, only in the context of the national treatment provision. ${ }^{66}$

\section{3. "Denial of Benefits"-Clauses}

"Denial of benefits"-clauses are also regularly included in Mega-Regionals as a tool to limit the application of the treaty in denying protection to certain investors and their investments. Such clauses attempt to deny treaty protection to "shell" or "mailbox" corporations that are controlled by nationals of a non-contracting state. "Denial of benefits"-clauses appear in the practice of both the United States and Canada, including in NAFTA. ${ }^{67}$ The most common ground upon which contracting states may deny the benefits of the treaty includes the situation where the investor is a national of a third party and has no substantial business activities in the territory of the contracting state. ${ }^{68}$ Some of the Mega-Regionals include this requirement in the definition of investor instead of in a separate "denial of benefits"-provision. ${ }^{69}$ Another ground that may trigger a "denial of benefits"-clause is where the investor is a national of a country with no diplomatic relations with the contracting parties. ${ }^{70}$ Some agreements add an additional requirement that the clause only operates subject to prior notification and/or consultation. ${ }^{71}$

\section{4. “In Accordance with Host State Law"-Clauses}

Finally, Mega-Regionals often use "in accordance with host state law"-clauses to limit the protection of investments made in conformity with domestic law. The NAFTA and the U.S. Model BITs do not have "in accordance with host state law"-clauses, but nonetheless arguably require as a general principle of law that

${ }_{66}$ EU-Singapore FTA, supra note 9, art. 9.3(3).

67 See, e.g., NAFTA, supra note 17, art. 1113; U.S. Model BITs 2004 and 2012, supra note 21, art. 17; Canada 2004 FIPA, supra note 38, art. 18.

68 See, e.g., NAFTA, supra note 17, art. 1113; U.S. Model BITs 2004 and 2012, supra note 21, art. 17; TPP, supra note 3, art. 9.15; ACIA, supra note 6, art. 19; ASEAN-PRC Investment Agreement, supra note 7, art. 15; ASEAN-AUS-NZ FTA, supra note 7, ch. 11, art. 11; ASEAN-Korea Investment Agreement, supra note 7, art. 17.

69 CETA, supra note 8, art. 8.1 defines "enterprise of a Party" as "an enterprise that is constituted or organized under the laws of that Party and has substantial business activities in the territory of that Party..." It also stipulates that an "investor" means "a Party, a natural person or an enterprise of a Party, other than a branch or a representative office, that seeks to make, is making or has made an investment in the territory of the other Party." This excludes shell companies from the protection of the agreement. Similarly, EU-Singapore FTA, supra note 9, art. 9.1.

70 See, e.g., NAFTA, supra note 17, art. 1113; U.S. Model BITs 2004 and 2012, supra note 21, art. 17; ACIA, supra note 6, art. 19.

71 Canada 2004 FIPA, supra note 38, art. 18(2); NAFTA, supra note 17, art. 1113(2); ACIA, supra note 6, art. 19; ASEAN-PRC Investment Agreement, supra note 7, art. 15(1); ASEAN-AUS-NZ FTA, supra note 7, ch. 11, art. 11; ASEAN-Korea Investment Agreement, supra note 7, art. 17(2). The "denial of benefits"-clauses in the ASEAN+ agreements make further special exceptions for Thailand and the Philippines. See ASEAN-PRC Investment Agreement, supra note 7, art. 15(2) and (3); ASEAN-AUS-NZ FTA, supra note 7, ch. 11, art. 11(3) and (4); ASEAN-Korea Investment Agreement, supra note 7, art. 17(4) and (5). 
investments be made in accordance with the rules of the domestic legal order. ${ }^{72}$ Mega-Regionals, however have decided to be more specific in their approach and have opted for one of two main approaches or forms of "in accordance with host state law"-clauses - one that ties compliance with domestic law to the definition of "covered investment" and one which limits the scope of application of the relevant investment treaty to investments made in compliance with domestic law. ${ }^{73}$ Although Mega-Regionals opt for different ways to frame an "in accordance with host state law"-clause, the legal effects are the same ${ }^{74}$ that is, they both deprive an illegal investment from the protection under the relevant investment treaty. Most MegaRegionals follow the first approach and include an "in accordance with host state law"-clause in the definition of "covered investment." " But at least one agreement follows the second approach and includes an "in accordance with host state law"-clause in the provision dealing with the scope of the relevant agreement. ${ }^{76}$ Either way, such clauses stress the continuous importance of domestic law for the regulation of foreign investment and thereby aim at ensuring additional host state policy space.

\section{B. REFormulation of Substantive Standards of TREATMENT}

Yet, Mega-Regionals not only ensure policy space by limiting the scope of application of investment treaty disciplines. They also seek to achieve a better balance between the protection and promotion of foreign investment and the policy space of host states, often in response to expansive interpretations of substantive standards by arbitral tribunals, by reformulating the substantive standards of protection. CETA and the EU's TTIP proposal are explicit in this regard; they each contain a separate provision that reaffirms a government's "right to regulate" for legitimate policy objectives, including for the protection of public health, safety and the environment. ${ }^{77}$ Other Mega-Regionals have opted for a more nuanced approach that makes room for regulatory objectives within the specific substantive provisions. Examples of this recalibration are, among others, clarifications to the provisions on direct and indirect expropriation (see Subsection 1), limitations on fair and equitable treatment (see Subsection 2), and restrictions on capital transfer provisions (see Subsection 3). All of this follows closely the developments under NAFTA and in the 2004 and 2012 U.S. Model BITs.

72 Stephan W. Schill, Illegal Investments in Investment Treaty Arbitration, 11 LaW \& PraC. InT'L CTS \& TRIBUNALS 281, 310-21 (2012).

73 Id. at $283-88$.

74 Id.

75 See, e.g., CETA, supra note 8, art. 8.1. The ACIA and ASEAN+ agreements all define "covered investment" subject to the "laws, regulations, and national policies" of a Member State. See ACIA, supra note 6, art. 4. See also ASEAN-Korea Investment Agreement, supra note 7, art. 1; ASEAN-AUS-NZ FTA, supra note 7, ch. 11, art. 2; ASEAN-PRC Investment Agreement, supra note 7, art. 1.

76 EU-Singapore FTA, supra note 9, art. 9.2.

77 CETA, supra note 8, art. 8.9; EU TTIP Proposal, supra note 4, sec. 2, art. 2. 


\section{Clarifications to Expropriation Provisions}

All Mega-Regionals include a provision that prohibits states from expropriating or nationalizing an investment except for a public purpose, in a non-discriminatory manner, in accordance with due process of law, and against payment of prompt, adequate, and effective compensation. ${ }^{78}$ Additionally, they often contain an annex similar in content to the U.S. and Canadian Model BITs that redefines the scope of protection under the expropriation clause in order to ensure sufficient regulatory space. ${ }^{79}$ However, the way this objective is achieved differs.

A first way to ensure regulatory space and to reduce constraints on government conduct is to follow the U.S. approach ${ }^{80}$ and link the expropriation provision to customary international law. An earlier draft of the TPP favored this option, ${ }^{81}$ but the final text of the TPP dropped the link between customary international law and the expropriation provision. ${ }^{82}$ A second method, which is also inspired by the U.S. Model BIT, ${ }^{83}$ is to clarify the object of expropriation and require that an expropriation can only occur if there is interference "with a tangible or intangible property right or property interest." 84 This links the determination of the object of an expropriation to the domestic legal system, which defines whether an investor's interest is given the characteristics of property, or whether it merely constitutes a privilege that can freely be revoked.

The third way is to limit specifically the scope of the concept of indirect expropriation. This is achieved in a variety of ways. CETA, for example, explicitly

78 See ASEAN-AUS-NZ FTA, supra note 7, ch. 11, art. 9(1)(a-d); ASEAN-Korea Investment Agreement, supra note 7, art. 12; ACIA, supra note 6, art. 14(1)(a-d); EUSingapore FTA, supra note 9, art. 9.6(1)(a-d); TPP, supra note 3, art. 9.8 (1)(a-d); CETA, supra note 8, art. 8.12(1)(a-d); see also ASEAN-PRC Investment Agreement, supra note 7 , art. 8(b) (instead of referring to due process of law, the agreement requires that the measure be "in accordance with applicable domestic laws, including legal procedures").

79 While the ACIA and ASEAN-AUS-NZ FTA both include an annex in regard to the expropriation provision (see ACIA, supra note 6, Annex 2 - Expropriation and Compensation; ASEAN-AUS-NZ FTA, supra note 7, Annex on Expropriation and Compensation, paras 1-4); the ASEAN-PRC and the ASEAN-Korea Investment Agreements do not have annexes.

80 U.S. Model BITs 2004 and 2012, supra note 21, annex B. The decision to limit the scope of the expropriation provision to that which exists at customary international law is arguably in response to the expansive interpretations given by arbitral tribunals in the NAFTA context. See, e.g., S.D. Myers v. Canada, UNCITRAL Arbitration Rules, Partial Award on the Merits (Nov. 13, 2000) para. 282.

81 Draft Trans-Pacific Partnership (June 2012), annex 12-B, available at http://www.citizenstrade.org/ctc/wp-content/uploads/2012/06/tppinvestment.pdf.

82 TPP, supra note 3, annex 9-A now only links the minimum standard of treatment provision to customary international law. TPP, supra note 3, art. 9.8 (Expropriation), by contrast, does mention customary international law, but only in a footnote clarifying the term "public purpose," which it delimits to a concept in customary international law.

83 U.S. Model BITs 2004 and 2012, supra note 21, annex B, para. 2. This type of limit may also have been developed in response to expansive interpretations by arbitral tribunals. See, e.g., S.D. Myers v. Canada, supra note 80, para. 281, where the tribunal asserted "in legal theory, rights other than property rights may be "expropriated."'

84 ACIA, supra note 6, annex 2, para. 1; ASEAN-AUS-NZ FTA, supra note 7, Annex on Expropriation and Compensation, para. 1; TPP, supra note 3, annex 9-B, para. 1. 
requires that an indirect expropriation occur only where a measure or series of measures exceeds a certain threshold by "substantially depriv[ing] the investor of the fundamental attributes of property in its investment." ${ }^{85}$ In addition, many agreements spell out a specific method for determining whether an indirect expropriation has occurred, or whether the government's measure remains a noncompensable regulation. In this regard, several Mega-Regionals are inspired by U.S. takings law, albeit with slight variations,${ }^{86}$ and require "a case-by-case, fact based inquiry" that considers certain factors. ${ }^{87}$ Under the TPP, which adopts the wording of the U.S. Model BIT verbatim, these are:

(i) the economic impact of the government action, although the fact that an action or series of actions by a Party has an adverse effect on the economic value of an investment, standing alone, does not establish that an indirect expropriation has occurred;

(ii) the extent to which the government action interferes with distinct, reasonable investment-backed expectations; and

(iii) the character of the government action. ${ }^{88}$

By providing a methodological blueprint, ${ }^{89}$ Mega-Regionals attempt to focus the task of arbitrators to a particular list of factors that should be considered when determining whether an indirect expropriation has occurred; in doing so, they limit the discretion of arbitrators and strengthen state control.

85 CETA, supra note 8, annex 8-A, para. 1.

86 See Penn Central Transportation Co. v. New York City, 438 U.S. 104 (1978) where the U.S. Supreme Court developed the criteria for deciding whether a particular governmental action constitutes a "taking" of property within the meaning of the Fifth Amendment of the U.S. Constitution.

87 See ACIA, supra note 6, annex 2, para. 3; ASEAN-AUS-NZ FTA, supra note 7, Annex on Expropriation and Compensation, para. 3; CETA, supra note 8, annex 8-A, para. 2; EUSingapore FTA, supra note 9, annex 9-A, para. 2; TPP, supra note 3, annex 9-B, para. 3(a).

88 Id. annex 9-B, para. 3(a)(i-iii). This is also the wording of the Canada 2004 FIPA, supra note 38 , annex B.13(1).

89 The factors to be considered vary from agreement to agreement. Most of the agreements require that the economic impact of the government action be taken into account (see, e.g., EU-Singapore FTA, supra note 9, annex 9-A; CETA, supra note 8, annex 8-A). Some agreements additionally require the duration of the measure to be assessed (see EU-Singapore FTA, supra note 9, annex 9-A, para. 2(a); CETA, supra note 8, annex 8-A), para. 2). Variations of the need for "reasonable investment-backed expectations" of the investor are also found in several agreements. ACIA and ASEAN-AUS-NZ FTA, for example, offer a narrower rendition and account for whether the "government action breaches the government's prior binding written commitment," whereas the EUSingapore FTA appears to offer broader coverage by requiring an examination into the extent to which the measure "interferes with the possibility to use, enjoy or dispose of the property" (see ACIA, supra note 6, annex 2, para. 3(b); ASEAN-AUS-NZ FTA, supra note 7, Annex on Expropriation and Compensation, para. 3(b); EU-Singapore FTA, supra note 9, annex 9-A, para. 2(b)). The character of the governmental action is a factor that seems to run through most Mega-Regionals but, again, slight variations exist. While some of the agreements follow the U.S. and TPP approach and simply refer to "the character of the government action," other agreements append a disproportionality analysis (see ASEAN-AUS-NZ FTA, supra note 7, Annex on Expropriation and Compensation, para. 3(c); ACIA, supra note 6, annex 2, para. 3(c)). 
The fourth way Mega-Regionals enhance the policy space of the host state under the expropriation provision is to include a specific exclusion from the expropriation provision for government regulation. The ACIA agreement includes the broadest regulation exclusion. It provides that "non-discriminatory measures of a Member State that are designed and applied to protect legitimate public welfare objectives ... do not constitute expropriation." ${ }^{90}$ Other agreements qualify the scope of the provision by adding the phrase "except in rare circumstances." approach taken in the Canada and U.S. Model BITs. ${ }^{92}$ In addition to this qualifier, CETA clarifies that:

except in rare circumstance where the impact of the measure or series of measures is so severe in light of its purpose that it appears manifestly excessive, non-discriminatory measures of a Party that are designed and applied to protect legitimate public welfare objectives, such as health, safety and the environment, do not constitute indirect expropriation. ${ }^{93}$

The inclusion of the words "manifestly excessive" arguably limits the scope of the provision even further. Despite the variance in threshold and scope, regulation exceptions appear to be a common tool of Mega-Regionals.

Together with both the introduction of a clear threshold that has to be passed before a measure can even be considered an expropriation and the listing of factors that need to be taken into account when determining whether an indirect expropriation has occurred, the exception for regulations aims at ensuring that legitimate government action for the protection of public interests does not constitute a direct or indirect expropriation.

\section{Limitations on Fair and Equitable Treatment}

A further example for how Mega-Regionals limit substantive standards in order to reserve policy space and strengthen state control concerns changes to the fair and equitable treatment standard. Similar to the provisions on expropriation, there are different means to achieve the end of limiting the standard's potency.

One way is to tie fair and equitable treatment to the standard offered by the domestic laws of the host state. ACIA can be seen, at last in the view of some, as adopting this approach. ${ }^{94}$ Its Article 11 provides that "[e]ach Member State shall accord investments of investors of any other Member State, fair and equitable treatment and full protection and security." 95 "For greater certainty," ACIA states,

90 ACIA, supra note 6, annex 2, para. 4. See ASEAN-AUS-NZ FTA, supra note 7, Annex on Expropriation and Compensation, para. 4. See also EU TTIP Proposal, supra note 4, annex 1, para. 3 .

91 CETA, supra note 8, annex 8-A, para. 3.

92 See U.S. Model BITs 2004 and 2012, supra note 21, annex B; Canada 2004 FIPA, supra note 38 , annex B.13(1).

93 CETA, supra note 8, annex 8-A, para. 3 (emphasis added).

94 See Diane Desierto, Regulatory Freedom and Control in the New ASEAN Regional Investment Treaties, 16 J. World Inv. \& TRAde 1018 (2015).

95 ACIA, supra note 6, art. 11(1). See also ASEAN-Korea Investment Agreement, supra note 7 , art. 5 . 
in the next paragraph, "fair and equitable treatment requires each Member State not to deny justice in any legal or administrative proceedings in accordance with the principle of due process. ${ }^{\circ 6}$ This may be read as requiring that the fair and equitable treatment provision is only breached when the government measure in question violates domestic notions of due process and denial of justice. ${ }^{97}$

Another approach is to tie fair and equitable treatment to customary international law. This is the approach first adopted under NAFTA through an authoritative interpretation of the agreement by the NAFTA Free Trade Commission, which explicitly linked the fair and equitable treatment to the minimum standard of treatment under customary international law. ${ }^{98}$ This interpretation was subsequently incorporated into the 2004 and 2012 U.S. Model BITs. ${ }^{99}$ The TPP follows this approach and clarifies that the fair and equitable treatment standard prescribes the "customary international [minimum] standard of treatment of aliens." 100 The TPP goes on to suggest that the fair and equitable treatment standard "includes the obligation not to deny justice in criminal, civil, or administrative adjudicatory proceedings" and incorporates a comparative analysis that takes into account due process principles "embodied in the principal legal systems of the world." 101

A third approach is to provide a closed list of elements, inspired by current arbitral interpretations that concretize the meaning of fair and equitable treatment. CETA, Article 8.10, for example, states that the obligation of fair and equitable treatment prohibits the following:

(a) Denial of justice in criminal, civil or administrative proceedings;

(b) Fundamental breach of due process, including a fundamental breach of transparency, in judicial and administrative proceedings;

(c) Manifest arbitrariness;

(d) Targeted discrimination on manifestly wrongful grounds, such as gender, race or religious belief;

(e) Abusive treatment of investors, such as coercion, duress and harassment; or

(f) A breach of any further elements of the fair and equitable obligation adopted by the Parties ... ${ }^{102}$

96 ACIA, supra note 6, art. 11(2)(a).

97 The ASEAN-PRC Investment Agreement, supra note 7, art. 7 has the same fair and equitable treatment standard with one modification. Instead of using "requires," the ASEAN-PRC Investment Agreement states "fair and equitable treatment refers to the obligation of each Party not to deny justice in any legal or administrative proceedings" (emphasis added). The U.S. Model BIT 2004, supra note 21, art. 5, for example, uses the word "includes."

98 See NAFTA Free Trade Commission, Notes of Interpretation of Certain Chapter 11 Provisions (July 31, 2001).

$99 \quad$ See U.S. Model BITs 2004 and 2012, supra note 21, art. 5(2)(a). See also Canada 2004 FIPA, supra note 38 , art. 5. The ASEAN+ agreements also tie the fair and equitable treatment provision to that which is required by customary international law. See, e.g., ASEAN-AUS-NZ FTA, supra note 7, ch. 11, art. 6(2)(c); ASEAN-Korea Investment Agreement, supra note 7, art. 5(2)(c).

100 TPP, supra note 3, art. 9.6(2).

101 Id. art. 9.6(2)(a). See also U.S. Model BITs 2004 and 2012, supra note 21, art. 5(2)(a).

102 CETA, supra note 8, art. 8.10. 
The provision's use of restrictive language, such as "fundamental breach," "manifest arbitrariness," and "targeted discrimination" signifies a high threshold for a breach of fair and equitable treatment. ${ }^{103}$ The provision further stipulates that the Parties shall periodically review the content of the fair and equitable treatment provision and make recommendations to the CETA Joint Committee. ${ }^{104}$ The use of a closed list of elements using restrictive qualifiers, coupled with a mechanism to amend the provision, arguably limits the discretion of future arbitral tribunals and increases the regulatory space of host states. ${ }^{105}$

The fair and equitable treatment is a ubiquitous, pervasive standard that has seen variable interpretations. The unpredictability of the standard is likely reflected in the various fair and equitable treatment provisions mentioned above. Nonetheless, parties to Mega-Regionals have all seized the opportunity to refine the scope, nature and content of fair and equitable treatment, taking steps to move away from a purely autonomous understanding of the standard, while clearly aiming to ensure the preservation of their policy space.

\section{Restrictions on Capital Transfer Provisions}

A final example of a provision commonly found in Mega-Regionals that provides states with greater flexibility and control, as compared to classical BITs, relates to restrictions placed on free capital transfer provisions. Reacting to recent financial crises, these restrictions provide states with the ability to control inflow and outflows of capital more effectively.

Traditionally, BITs included "open-ended transfer rights."106 Today, however, beginning with NAFTA, ${ }^{107}$ many Mega-Regionals contain exceptions that include, for example: (i) bankruptcy, insolvency, and protection of the rights of creditors; (ii) issuing, trading or dealing in securities; (iii) criminal or penal offences; (iv) ensuring compliance with orders or judgments in judicial or administrative proceedings; and (v) taxation. ${ }^{108}$ Departing from U.S. practice, ${ }^{109}$ NAFTA along with some Mega-Regionals go a step further and are accompanied with safeguard

103 This resonates of certain NAFTA arbitral tribunal's interpretation of Article 1105(1). Cf. Glamis Gold v. United States, UNCITRAL Arbitration Rules, Award (June 8, 2009) paras. 614-616.

104 The article also stipulates that the Tribunal "may take into account" the legitimate expectations of the investor.

105 The EU-Singapore FTA also makes use of lists to concretize what fair and equitable treatment means. It differs from CETA in an important aspect. Unlike CETA, it includes a breach of the investor's legitimate expectations as part of the closed list (EU-Singapore FTA, supra note 9, art. 9.4(2)(e)). CETA, by contrast, merely provides that a tribunal "may take into account" the investor's legitimate expectation in interpreting the listed elements (CETA, supra note 8, art. 8.10(4)) (emphasis added).

106 Andrew Newcombe \& Lluis Paradell, Law and Practice of Investment Treaties 414 (2009).

107 NAFTA, supra note 17, art. 1109(4).

108 See, e.g., EU-Singapore FTA, supra note 9, art. 9.7(2); TPP, supra note 3, art. 9.9(4); CETA, supra note 8, art. 8.13(3); ACIA, supra note 6, art. 13(3).

109 The 2012 U.S. Model BIT does not contain a balance-of-payments exception. See U.S. Model BIT 2012, supra note 21, art. 7 (Transfers). 
provisions in case of serious balance-of-payments difficulties. ${ }^{110}$ The ACIA and ASEAN+ agreements, for example, have such safeguards. Thus, under ACIA, "[i]n the event of serious balance-of-payments and external financial difficulties or threat thereof" Member States are allowed to "adopt or maintain restrictions on payments or transfers related to investments." 111

Outside the ASEAN framework, safeguard provisions are also present. ${ }^{112}$ Using almost identical wording as ACIA, CETA and TPP make reference to the Articles of Agreement of the International Monetary Fund (IMF Articles) and permit Parties to adopt or maintain temporary safeguard measures where serious balanceof-payments problems or external financial difficulties, or threats thereof, exist. ${ }^{113}$ The EU-Singapore Free Trade Agreement also includes a safeguard provision; however, it does not make reference to the IMF Articles. It permits Parties to take safeguard measures "[w]hen in exceptional circumstances, capital movements cause or threaten to cause serious difficulties for the operation of monetary policy or exchange rate policy in either Party." These measures must be temporary, "strictly necessary," and require the Party adopting the measures to inform the other Party of a time schedule for their removal. ${ }^{114}$

Mega-Regionals, arguably influenced by NAFTA's Article 2104, recognize that exceptional circumstances can exist in which a host state should maintain the flexibility to introduce measures that restrict transfers where the party experiences serious balance-of-payments difficulties, or threat thereof. Notwithstanding minor distinctions, restrictions on capital transfer provisions in Mega-Regionals have become important tools to reduce financial vulnerability in times of crisis, thereby ensuring that governments can act efficiently to protect public interests.

\section{InSTitutional SAFEGUARDS}

Finally, many Mega-Regionals not only aim at providing additional policy space to host states by recalibrating the applicable standards of treatment. They also introduce institutional safeguards that seek to reign in some of the discretion given to arbitral tribunals in the interpretation of the broadly worded standards of treatment and to place power back into the hands of states.

One such institutional safeguard, first adopted under NAFTA, ${ }^{115}$ and later advanced in U.S. Model BITs, ${ }^{116}$ is the establishment of committees with

110 See NAFTA, supra note 17, art. 2104.

111 ACIA, supra note 6, art. 16. These restrictions must be (i) consistent with relevant International Monetary Fund provisions; (ii) avoid unnecessary damage to the commercial, economic, and financial interests of another Member State; (iii) not exceed those necessary to deal with the circumstances; (iv) applied for a limited period of time; and (v) taken in a nondiscriminatory manner (id. art. 16(2)). See also ASEAN-Korea Investment Agreement, supra note 7, art. 11; ASEAN-PRC Investment Agreement, supra note 7, art. 11; ASEAN-AUS-NZ FTA, supra note 7, art. 8(4).

112 TPP, supra note 3, art. 29.3; CETA, supra note 8, art. 28.5. See also EU-Singapore FTA, supra note 9 , art. 9.7(3).

113 TPP, supra note 3, art. 29.3; CETA, supra note 8, art. 28.5.

114 EU-Singapore FTA, supra note 9, art. 9.7(3).

115 NAFTA, supra note 17, art. 1131.

116 U.S. Model BITs 2004 and 2012, supra note 21, art. 30(3). 
representatives of the contracting parties that have the competence to adopt authoritative interpretations of the investment protection standards that are binding on arbitral tribunals. This permits the Parties to provide indications as to how they wish the agreement to be interpreted. In the case of CETA, this mechanism is expressly not only thought for issuing binding interpretations, but also to allow Parties to adapt, and add content to, the fair and equitable treatment standard. ${ }^{117}$

Another institutional mechanism that is foreseen by certain Mega-Regionals is the establishment of an appellate mechanism that could oversee decisions by arbitral tribunals under the respective agreement. ${ }^{118}$ Other than the CETA, which includes an appellate mechanism, ${ }^{119}$ Mega-Regionals so far only offer the possibility of introducing such a mechanism in the future; but this may well change with the ongoing discussions in the EU about the appropriate institutional structure for investor-state dispute settlement. CETA, for example, establishes an appellate tribunal that may "uphold, modify or reverse a Tribunal's award" based on errors in the application or interpretation of applicable law, manifest errors in the application of the facts, and grounds set out under Article 52(1) of the ICSID Convention. Independently of the prospects of whether Mega-Regionals will actually create an appellate structure for investment dispute settlement more generally, the institutional safeguards they foresee are part of the larger trend of shifting control from arbitral tribunals back to states in parallel with the limits introduced to the scope of application of investment treaties and the recalibration of substantive standards of treatment.

\section{The Impact of Mega-Regionals on International INVESTMENT LAW}

Mega-Regionals have transformed substantive investment protection standards in a way that has met the treaty parties' goals of investment liberalization and greater sovereign control over the system of international investment law. This section critically analyzes the transformation of international investment law MegaRegionals will bring about. In the first part, Mega-Regionals will be contextualized from the perspective of the current trends in international investment law (see Section A). In the second part, the reasons for the evolution in the content of Mega-Regionals will be discussed (see Section B). All in all, viewing Mega-Regionals in this broader context reinforces the view that the transformation of international investment law takes shape through developments that first took root in NAFTA, and the experience made in particular by the United States, and later spread to the global level.

\footnotetext{
117 See, e.g., CETA, supra note 8, arts. 8.10(3) and 8.44(3)(d). See also EU-Singapore FTA, supra note 9, art. 9.33. Likewise, the EU TTIP Proposal envisages a provision that will allow the Committee to adopt decisions interpreting investment protection provisions in cases where "serious concerns arise as regards matter of interpretation." See EU TTIP Proposal, supra note 4, subsec. 2, art. 13(5).

118 TPP, supra note 3, art. 9.23, para. 11; EU-Singapore FTA, supra note 9, art. 9.33; EU TTIP Proposal, supra note 4, subsec. 2, art. 10; CETA, supra note 8, art. 8.44(3)(e).

119 CETA, supra note 8, art. 8.28.
} 


\section{A. Fusing MEGa-TRENDS IN INTERNATIONAL INVESTMENT LAW}

The content of Mega-Regionals appears to be moving in parallel with the major trends found in investment treaty making more generally. ${ }^{120}$ However, like a loom, Mega-Regionals take different trends in international investment law and interlace them to form a unique fabric for the future of global economic governance. In fact, Mega-Regionals weave together four mega-trends in international investment law, all of which are foreshadowed by U.S. and NAFTA practices.

The first trend is the combination of trade and investment rules into one agreement. This amalgamation of trade and investment governance arguably exhibits a movement towards deeper integration of international economic law and recognition of the inherent interconnection between these two areas of law. ${ }^{121}$ While the integration of trade and investment rules has been common practice for Canada and the United States since the conclusion of the Canada-United States Free Trade Agreement in 1988, ${ }^{122}$ which later inspired NAFTA and many other U.S. trade and investment agreements, this is a newer development for the EU given that it was only granted competence for "foreign direct investment" in the Lisbon Treaty. ${ }^{123}$ The EU has now started putting this competence into practice and has concluded negotiating trade and investment agreements with Canada, Singapore and Vietnam. Further treaties of this nature are currently being negotiated inter alia, with India, China, Malaysia and Thailand. ${ }^{124}$ At the same time, the trend to combine rules on trade and investment can be found in virtually any other Mega-Regional, whether TPP, TTIP, or RCEP.

The second trend is the growth of regionalism in international investment law, which involves two components: first the rise in regional agreements granting investment protection to its members, and second the increasing involvement of regional organizations as parties to international investment agreements. ${ }^{125}$ NAFTA, in fact, is an example of the first category. The trend towards regionalism in both senses can also be detected in Mega-Regionals. First, Mega-Regionals are instruments that grant, as regional agreements, investment protection to the participating members. Mega-Regionals are either inter-regional agreements (that connect treaty parties from two or more different geographical regions) or intraregional agreements (that connect treaty parties from within one geographical

120 For a discussion of these trends, see Stephan W. Schill \& Marc Jacob, Trends in International Investment Agreements, 2010-2011: The Increasing Complexity of International Investment Law, in Yearbook on International Investment LaW and Policy 2011-2012 145 (Karl P. Sauvant ed., 2012).

121 See Tomer Broude, Investment and Trade: The "Lottie and Lisa" of International Economic Law?, in Prospects in International Investment Law and Policy 139-55 (Roberto Echandi \& Pierre Sauvé eds., 2013).

122 Canada-United States Free Trade Agreement, ch. 16, Jan. 2, 1988, available at http:// www.international.gc.ca/trade-agreements-accords-commerciaux/assets/pdfs/cusfta-e. pdf.

123 See Treaty on the Functioning of the European Union, arts. 207(1) and 3(1)(e).

124 See European Commission, Overview of FTA and Other Trade Negotiations (Jan. 27, 2015), available at http://trade.ec.europa.eu/doclib/docs/2006/december/tradoc_118238. pdf.

125 See further the contributions in REGIONALISM In INTERNATIONAL INVESTMENT LAW (Leon E. Trakman \& Nicola W. Ranieri eds., 2013). 
region). The inter-regional type would include the TPP, which links Asia, Australia, and the Pacific side of the Americas, and the TTIP, connecting the EU and the United States. Intra-regional agreements would include ACIA, which includes an internal investment agreement amongst ASEAN members, or RCEP, which links different countries in the Asia-Pacific region. Second, many Mega-Regionals also involve regional organizations as treaty parties, most notably the EU and ASEAN.

The third trend in international investment law, which also reflects in MegaRegionals, is the recalibration of international investment law in terms of both investor-state dispute settlement and substantive standards, which is inspired by developments in U.S. and NAFTA practices on the protection of foreign investment. As discussed, Mega-Regionals contain rules that are different from those in traditional BITs and aim at striking a more appropriate balance between investor protection and non-investment related public interests. This trend reflects, inter alia, in more elaborate agreements with greater specificity, clarifications, exceptions and carve-outs, more refined substantive investment protection standards, and the introduction of institutional safeguards to influence the interpretation of the agreements. ${ }^{126}$

Finally, the fourth trend that is reflected in Mega-Regionals is a shift in the geography of international investment law, which is discernible in two movements. The first is the shift in focus from transatlantic to transpacific treaty making. The second is the shift away from Europe and North America, as the two so far prevailing capital-exporting regions and most significant rule-makers in international investment law, to Asia. While CETA and TTIP are both attempts to maintain the momentum of transatlantic rule-making in global economic governance, the importance of Mega-Regionals with a specific focus on the Asia-Pacific region, including TPP, ACIA, and RCEP, illustrate the general shift in international investment law from a transatlantic to a transpacific focus. While NAFTA, as well as the U.S. Model BIT, still remain strong blueprints for international investment agreements, with the changing geography and the strong participation of Asian actors in Mega-Regionals, "the future center of investment treaty-making [may move] eastwards: from its current focus on transatlantic cooperation towards AsiaPacific and transpacific cooperation." 127

As shown, Mega-Regionals, following on the threads of NAFTA and U.S. practices, weave together these major trends in international investment law, including the unification of trade and investment into one agreement, the rise of regionalism, the recalibration of investment standards, and the shifting geography. How the eventual fabric of international investment law will look like, however, is still subject to speculation at this point. Much will depend on how (and if) the EU and the United States manage to conclude TTIP. If TTIP materializes as planned, the EU and the United States will likely maintain a strong foothold on rule-making power in international investment law. If these negotiations fail, the pattern may change towards displaying stronger threads of the Asia-Pacific Region. Be that as it may, Mega-Regionals, not BITs, are going to be the instruments shaping the future of international investment law. Mega-Regionals, not BITs, are going to determine what the standards will be for the governance of investor-state relations in the future.

126 See supra Part III.

127 Schill \& Jacob, supra note 120 , at 143. 


\section{B. Structural Differences Between Mega-Regionals and Traditional BITS}

As can be seen in relation to the major trends, Mega-Regionals are departing from the architecture of traditional BITs. However, Mega-Regionals are not merely evolved versions of modernized BITs. Instead, Mega-Regionals have emerged as unique agreements that attempt to achieve the twin goals of investment liberalization and increasing state control. To do this, Mega-Regionals have recalibrated substantive standards of investment protection in a way that is both innovative and ambitious. The changes to substantive standards of treatment are not solely caused by changes in preferences and policy. The changes are also due to deeper structural reasons, including changes in the structure of contracting parties (see Subsection 1), the amalgamation of trade and investment (see Subsection 2), and renewed interest of the general public in all stages of investment treaty making (see Subsection 3).

\section{More and Different Contracting Parties}

Compared to traditional BITs, contracting parties involved in Mega-Regionals are different in two main respects. First, the number of contracting parties has expanded from simple two-party bilateral arrangements to complex and intricate treaty negotiations between a wide range of parties. Mega-Regionals have been concluded, for instance, between countries from a particular region (e.g. ACIA), between countries from around the world (e.g. the TPP), and between individual countries and supra-national organizations (e.g. the EU) or regional trading blocs (e.g. RCEP). With an increase in numbers of contracting parties, Mega-Regionals must accommodate more interests. This reflects both in more, and more specific, exceptions, like the TPP tobacco carve-out, ${ }^{128}$ but also in a generally more limited level of substantive investment protection compared to traditional BITs, reflecting the need to find an often lower common denominator. ${ }^{129}$

Second, the contracting parties involved in Mega-Regionals are different in character. Typically, traditional BITs were concluded principally between capital-exporting countries (i.e. countries in Europe and North America) and capital-importing, developing countries. The underlying rationale for most of these agreements was to protect investors from developed countries who invested in developing countries against illegitimate government conduct, such as expropriations without compensation or other types of illegitimate interferences with their investment. Although at a formal level these agreements were reciprocal in nature, as both parties undertook the same obligations, "in practice the obligations all fell on the developing country party." ${ }^{130}$ Consequently, the substantive standards of protection in the agreements were formulated with the protection of investors from developed countries in mind (but not necessarily the other way around). This led to language with no, or few, public interest-related exceptions or clarifications. The agreements instead covered investments in a broad sense and listed the traditional range of investor guarantees, including fair and equitable treatment, full

\footnotetext{
See TPP, supra note 3, art. 29.5.

See supra Part III.

130 Kenneth J. Vandevelde, A Brief History of International Investment Agreements, 12 U.C. DaVIS J. INT'L L. \& PoL'y 157, 171 (2005).
} 
protection and security, non-discrimination, and the prohibition of expropriations without much attention to host state regulatory space.

In contrast, Mega-Regionals reflect a changed environment in which investment flows are no longer unidirectional; instead they flow both ways. Treaties, in consequence, no longer solely accommodate the offensive interests of capital-exporting countries, but are negotiated from the start based on an overall assessment of offensive and defensive interests by every negotiating party, whether developed or developing. With investments flowing in two ways, Mega-Regionals have altered the matrix underlying the negotiation of investment disciplines, and for this reason come along with recalibrated substantive standards of treatment that not only contain rules on investment protection, but also emphasize host state policy space.

\section{Combination of Rules on Trade and Investment}

The second major structural difference between Mega-Regionals and traditional BITs, as mentioned above, is the combination of trade and investment in one agreement. ${ }^{131}$ Customarily, investment promotion and protection treaties were selfstanding agreements that focused exclusively on investment protection and ignored any connection investment may have had with trade. ${ }^{132}$ Mega-Regionals (re)unite trade and investment rules as part of one field of international economic law. The effect of this combination may explain some of the changes in substantive standards of treatment, which are no longer generated solely in the context of the investment regime, but are recalibrated under the influence of international trade law.

First, with trade and investment rules now being negotiated side-by-side, there is an increase in the potential for cross-deals. In BIT negotiations, by contrast, where the sole focus is on the level of investment protection, cross-deals (more or less investment protection in exchange for concessions in other areas of negotiation) were practically non-existent. However, in Mega-Regionals, contracting parties may concede a certain level of substantive investment protections in exchange for a more favorable deal in another sector. In this way, negotiators may strategically use or demand concessions on investment protection and investor-state dispute settlement as bargaining chips to cut cross-issue deals. This may explain, to a certain extent, differences in the investment rules agreed to under Mega-Regionals.

Second, unlike with the negotiations of BITs, which usually involved one or two ministries of the contracting parties (depending on the internal organization, often the ministry for economic affairs and the foreign ministry), Mega-Regionals mandate greater involvement from multiple departments of government, including, for example, ministries for social affairs, environment, etc., with each of them having different interests, expertise, and new ideas. These actors already have been involved for a long time in the negotiation of trade agreements and now, with the reunion of investment and trade, also get involved in the negotiation of investment

31 See supra Part IV, Sec. A.

132 Alireza Falsafi, Regional Trade and Investment Agreements: Liberalizing Investment in a Preferential Climate, 36(1) Syracuse J. InT'L L. \& COM. 43, 45 (2008). This is not an entirely new trend, however. In fact, the Friendship, Commerce and Navigation (FCN) treaties the United States had started concluding in the $19^{\text {th }}$ century traditionally addressed investment and trade aspects in one agreement. 
rules. The increased involvement at the domestic level is likely responsible for longer and more complicated negotiations that result in treaties containing more exceptions and more elaborate provisions, but that also exhibit more complete approaches to economic governance.

Finally, the combination of trade and investment rules in Mega-Regionals blends the trade and investment law communities. This also has repercussions on how the substantive rules of investment protection in Mega-Regionals are crafted and applied as compared to traditional BITs. ${ }^{133}$ While trade lawyers traditionally had little impact on shaping the rules governing investor-state relations, their interaction with investment lawyers in the context of Mega-Regionals may lead both to occasional struggle, when different perspectives and underlying philosophies collide, but also to increased cross-fertilization. ${ }^{134}$ One example of this cross-fertilization is the inclusion of general exception clauses that mirror GATT Article XX in Mega-Regionals. ${ }^{135}$ The appearance of such clauses would have been unlikely without the spill-over of similar debates about the relationship between economic and non-economic concerns from trade to investment. Likewise, the blending of trade and investment communities may also have the potential to embed investment law more firmly into the public international law system, where the trade law system firmly stands.

All in all, the combination of trade and investment in one agreement is a gamechanger that not only affects the general impact of Mega-Regionals as pillars of global economic governance, but also accounts for further developments of the investment provisions contained in the agreements.

\section{Increased Public Attention}

The final structural difference with classical BITs consists in the greater public attention to the negotiation, ratification and implementation of Mega-Regionals. Traditionally, BITs were negotiated quietly and with little, if any, public attention. Mega-Regionals differ radically in this respect and attract public attention in all stages of treaty making. This is mainly due to the fact that Mega-Regionals have a broader coverage of interests, including environmental, human rights and labor issues, and involve more stakeholders. With the increase in potential impact of Mega-Regionals on those interests, more members of the public and more special interest groups, including non-governmental organizations, get involved in the political process surrounding the negotiation of Mega-Regionals. This not only indirectly affects the negotiations of Mega-Regionals; it may have concrete influence on the procedures through which negotiation positions in different constituencies are formed. In the EU, for example, the European Commission launched an

\footnotetext{
133 After all, the socialization of lawyers and the sociological composition of those who engage in the negotiation and application of investment rules influences their substance. $C f$. Stephan W. Schill, W(h)ither Fragmentation? On the Literature and Sociology of International Investment Law, 22 EUR. J. INT'L L. 875 (2011).

134 See, e.g., Nicholas DiMascio \& Joost Pauwelyn, Non-Discrimination in Trade and Investment Treaties: World Apart or Two Sides of the Same Coin?, 102 Am. J. INT'L L. 48 (2008); Jürgen Kurtz, The WTO and International Investment Law: Converging SYSTEMS (2016).

135 See supra Part III, Sec. A.2.
} 
online public consultation on investment protection and investor-state dispute settlement in TTIP to channel criticism and to improve communication between those who negotiate Mega-Regionals and the general public. ${ }^{136}$ The outcome of this consultation has subsequently influenced the EU's stance on investment protection in the proposal made to the United States for TTIP's investment chapter. ${ }^{137}$ This shows that increased public attention fundamentally changes the negotiation process and has repercussions on the content of the agreements, including the substantive standards of investment protection.

Examples, where the increase in public attention has had practical consequences for the content of Mega-Regionals are the inclusion of more exceptions, carveouts, and clarifications that aim to protect host state policy space and interests the public is particularly concerned about. In addition, with an increase in public attention come corresponding demands for greater transparency, both as regards the negotiation of Mega-Regionals, but also their implementation, including through investor-state dispute settlement. This explains the inclusion of provisions on transparency that grant the public access to documents that are relevant for arbitral proceedings ${ }^{138}$ and to hearings ${ }^{139}$ and that allow amici curiae to make submissions in arbitration proceedings. ${ }^{140}$ Finally, increasing public attention may also lead to greater difficulties for the conclusion, ratification and implementation of MegaRegionals, as critics of these agreements start organizing themselves and using political fora and campaigns, but potentially also court proceedings to influence the content of these agreement or even block them altogether.

Mega-Regionals have important structural differences compared to traditional BITs in that they seek to balance the goals of investment liberalization and increasing state control. These structural changes were first witnessed with NAFTA, which already combined more than two contracting parties, including two developed and one developing country, fused trade and investment into one agreement, and started to attract public attention in the mid-1990s after claims were advanced by investors under NAFTA Chapter 11 and subsequently responded to greater demands for transparency.

136 European Commission, European Commission Launches Public Online Consultation on Investor Protection in TTIP, Press Release, Mar. 27, 2014, available at $\mathrm{http}: / / \mathrm{europa}$. eu/rapid/press-release_IP-14-292_en.htm. The European Commission received almost 150,000 responses to its online consultation. See European Commission, Report on the Online Public Consultation on Investment Protection and Investor-to-State Dispute Settlement (ISDS) in the TTIP, Brussels, Jan. 1, 2015, Commission Staff Working Document 2015 SWD (2015) 3 final, available at http://trade.ec.europa.eu/doclib/ docs/2015/january/tradoc_153044.pdf.

137 EU TTIP Proposal, supra note 4.

138 See, e.g., TPP, supra note 3, art. 9.24(1) (Transparency of Arbitral Proceedings); EUSingapore FTA, supra note 9, annex 9-C, art. 1 (Rules on Public Access to Documents, Hearings and the Possibility of Third Persons to Make Submissions); CETA, supra note 8 , art. 8.36 (Transparency of Proceedings).

139 See, e.g., TPP, supra note 3, art. 9.24(2) (Transparency of Arbitral Proceedings); EUSingapore FTA, supra note 9, annex 9-C, art. 2 (Rules on Public Access to Documents, Hearings and the Possibility of Third Persons to Make Submissions); CETA, supra note 8, art. 8.36 (Transparency of Proceedings).

140 See, e.g., TPP, supra note 3, art. 9.23(3); EU-Singapore FTA, supra note 9, annex 9-C, art. 3 (Rules on Public Access to Documents, Hearings and the Possibility of Third Persons to Make Submissions). 


\section{Concluding Remarks}

Mega-Regionals are cutting-edge agreements that are transforming the substantive standards of investment protection in a way that simultaneously seeks to achieve two main policy goals. First, Mega-Regionals promote investment liberalization through greater market access commitments. Second, Mega-Regionals strengthen state control in order to ensure that governments have sufficient space to regulate in the public interest. In pursing these twin-goals, Mega-Regionals both introduce new limits on states at the pre-establishment phase, including non-discriminatory treatment provisions and restrictions on performance requirements, and strengthen state powers at the post-establishment phase, by limiting the scope of investment protection standards, reformulating substantive standards of treatment, and including certain institutional safeguards.

Yet, Mega-Regionals are more than just one trend in international investment law. They are contributing to transforming international investment law more generally. Mega-Regionals can be likened to a loom that weaves all major trends in investment treaty making together, including the amalgamation of investment and trade law, strengthening regionalism, recalibrating investment disciplines, and changing the geographical landscape of international investment law. In addition to being investment "trendsetters," Mega-Regionals also reflect deeper structural changes to international economic governance as compared to traditional BITs. These changes result from differences in contracting parties, the linking of trade and investment, and the increased public attention in the treaty-making process. Provided MegaRegionals will materialize as currently negotiated, they are likely to constitute the new blueprints for rules and institutions of international economic governance more generally. In the investment law context, they will replace the structure and content of traditional and lean European-style BITs with the more elaborate provisions that follow the treaty practices under NAFTA and of the United States.

Considering the influence of the United States, directly and via NAFTA, on the form and content of investment rules in Mega-Regionals, a key question for the future will be whether the United States can continue to exercise its rule-shaping power for international investment relations, or whether we will see the rise of new rule-shapers. Actors from Asia are certainly candidates for such a position, not only in light of the region's growing economic importance, but also because several Asian actors are engaged in a critical rethink of international investment policy that may potentially have global repercussions. ${ }^{141}$ At present, however, it is still too early to tell how powerful Asian actors are going to be in this respect - not least because many of them still face considerable obstacles in assuming global leadership in the field. Moreover, the United States is strongly engaged in investment treaty negotiations with actors in the Pacific and hence seems well-placed to exercise its rule-shaping power, which is influenced and modeled on its NAFTA experience and subsequently recalibrated Model BITs.

The other important rule-shaper in international investment law with global ambitions is, of course, the EU. Its proposal to replace investor-state arbitration

${ }_{141}$ See the contributions in Stephan W. Schill (ed.), Special Issue: Dawn of an Asian Century in International Investment Law?, 16 J. WorLd Inv. \& TRAdE 765-1123 (2015). 
with an 'investment court system' is likely going to lead to a struggle for intellectual leadership with the United States about forging the rules and institutions of the future in international investment law. ${ }^{142}$ When looking at the substantive rules on international investment protection, by contrast, the U.S. approach is still dominant. Except for the EU's position to lay down the right to regulate as an express treaty provision, its stance on substantive investment protection rules more generally is very influenced by the recalibrated U.S. approach as laid down in the U.S. Model BITs of 2004 and 2012. At least, in this respect, the EU is not developing its own, distinctly European approach. Independently of whether TTIP negotiations conclude successfully, and whether international investment lawmaking will continue to be shaped in transatlantic relations, there is little doubt that the substance of international investment relations is likely going to reflect the brave new American world of international investment treaty making. What will be crucial to ensure, however, is that this world does not only reflect American values and preferences, but a just international economic order under the rule of law that is universally accepted.

142 See Stephan W. Schill, US versus EU Leadership in Global Investment Governance, 17 J. World Inv. \& TRADE 1 (2016). 